\title{
Progress in Microbial Activity and Chemical Properties of a Trace Element Polluted Soil Under Assisted Natural Remediation
}

\author{
Alfredo Pérez-de-Mora, Pilar Burgos, Francisco Cabrera \\ and Engracia Madejón
}

Abstract In this work, we studied the temporal dynamics of several microbiological properties in a trace element polluted soil under the influence of various amendments and/or a plant cover during a 30 month-period. The experiment was carried out in containers filled with ca. $150 \mathrm{~kg}$ of contaminated soil. Seven treatments were established: four organic (leonardite LEO, litter LIT, municipal waste compost MWC and biosolid compost $\mathrm{BC}$ ) and one inorganic (sugarbeet lime SL), where the grass Agrostis stolonifera $\mathrm{L}$. was sown, and two control treatments (with plant CTRP or without plant CTR). Soil was sampled four times during the experimental period. The microbiological properties studied were: microbial biomass $\mathrm{C}$, microbial biomass $\mathrm{C} /$ total organic $\mathrm{C}$, dehydrogenase, aryl-sulphatase, $\beta$-glucosidase, acid-phosphatase and protease enzyme activities. Dynamics of microbiological properties differed between treatments being results not only affected by soil $\mathrm{pH}$ or trace element concentrations, but also by changes derived from the different treatments in organic matter quality and quantity, as well as nutrient content in soil. While microbial biomass $\mathrm{C}$, dehydrogenase, arylsulphatase and protease activities were highly correlated with soil $\mathrm{pH}$ and soluble trace element contents, changes in $\beta$-glucosidase activity were mainly influenced by water soluble $\mathrm{C}$ concentrations. It was also observed that enzymatic activities generally decreased over time after no more amendment additions occurred. Nonetheless, during the experiment microbial biomass and activities were generally higher in all treatments compared to the untreated control and thus remediation practices had a positive and significant effect on trace element stabilization and microbial activity in the contaminated soil. 


\section{Introduction}

Mining activities can release significant amounts of trace elements such as As, Cd, $\mathrm{Cu}, \mathrm{Pb}$ and $\mathrm{Zn}$ into the environment negatively affecting organisms and ecological processes within atmospheric, aquatic and terrestrial systems (Iskandar and Adriano 1997). In terrestrial systems, trace elements tend to accumulate in the surface of soils due to binding with its components (clay minerals, iron/manganese oxides, organic matter, etc.) in a variety of ways. Owing to its small size and crucial role in nutrient cycling, the soil microbiota is the first group of organisms that undergoes direct and indirect impact due to accumulation of trace elements in soil (Giller et al. 1998). Although high concentrations of trace elements may promote the development of tolerant microbial populations (Ellis et al. 2003), trace element polluted soils generally show less microbial biomass and altered microbial activity patterns compared to non-affected soils (Kandeler et al. 2000). Among the different methodologies to assess microbial activity in soil, enzymatic assays, either based on colorimetric or fluorescence reactions, have been widely used due to: (1) their specificity, (2) their simplicity and (3) the integrative nature of enzymatic activities, from the micro-up to the macroscale (Nannipieri et al. 2002). Soil enzymatic assays may be therefore used to evaluate not only anthropogenic disturbances such as those related to contaminant accumulation, but also restoration and remediation practices in affected systems. Since trace elements cannot be degraded, remediation of soils polluted with trace elements is based either on the extraction or the stabilization of the contaminants. Among stabilization techniques, assisted natural remediation has been proposed as a potential low-cost and environmentally friendly alternative to treat extensive areas moderately contaminated (Madejón et al. 2006). This technique is based on the use of amendments to accelerate those processes (sorption, precipitation and complexation reactions) that take place naturally in soils and reduce the mobility and bioavailability of toxic elements (Bolan and Duraisamy 2003). In addition to the incorporation of amendments, the development of a plant cover may prevent wind-blow of contaminated particles and reduce water pollution (Tordoff et al. 2000). There is, however, concern regarding the longevity of utilizing amendments to assist natural remediation. Reacidification of soil may reverse the action of amendments that make soils more alkaline. Mineralization of organic matter present in biosolids may also release trace elements in potentially bioavailable forms. Traditionally, repeated applications of amendments have been recommended to maintain trace element immobile, but more work is required to refine these procedures and understand the effects of such practices on soil dynamics in the mid-and long-term.

Stabilization techniques aim at immobilizing trace elements in the soil to reduce their availability to biological targets, run-off transport and leaching. However, reliance on abiotic properties is insufficient to assess the efficiency of remediation practices from an environmental perspective. Alternative parameters are required which can be used as bioindicators to monitor changes in soil ecological processes such as those related to anthropogenic and natural disturbances, 
Table 1 Mean values \pm standard deviation of some chemical characteristics of the soil

\begin{tabular}{llc}
\hline pH & & $3.32 \pm 0.76$ \\
TOC & $\mathrm{g} \mathrm{kg}^{\mathrm{a}}$ & $5.40 \pm 0.07$ \\
Tot-As & $\mathrm{mg} \mathrm{kg}^{-1}$ & $120 \pm 3$ \\
Tot-Cd & $\mathrm{mg} \mathrm{kg}^{-1}$ & $2.43 \pm 0.04$ \\
Tot-Cu & $\mathrm{mg} \mathrm{kg}^{-1}$ & $78.3 \pm 1.4$ \\
Tot-Mn & $\mathrm{mg} \mathrm{kg}^{-1}$ & $645 \pm 25$ \\
Tot-Pb & $\mathrm{mg} \mathrm{kg}^{-1}$ & $201 \pm 6$ \\
Tot-Zn & $\mathrm{mg} \mathrm{kg}^{-1}$ & $226 \pm 3$ \\
\hline
\end{tabular}

TOC total organic carbon

remediation practices or land management. Enzymatic activities are particularly attractive for this purpose due to their crucial role in soil organic matter transformations and their direct link to the soil microbiota.

The aim of this study was to evaluate the mid-term effects of various amendments and/or a plant cover on trace element stabilization and the different processes related to the cycling of nutrients $(C, N, P$ and $S$ ) in a soil moderately contaminated with $\mathrm{As}, \mathrm{Cd}, \mathrm{Cu}, \mathrm{Pb}$ and $\mathrm{Zn}$. A 30 month experiment was conducted in containers to simulate potential field remediation practices under more controlled conditions. In addition to trace element availability, general soil physical and chemical characteristics as well as various microbiological and biochemical properties were investigated.

\section{Materials and Methods}

\subsection{Soil Characteristics}

Soil was sampled in an area affected by the Aznalcóllar mine accident named "El Vicario", where the only remediation work carried out by the authorities was the removal of the sludge layer together with the first $15 \mathrm{~cm}$ of topsoil. The soil was clayey loamy classified as Typic Xerofluvent (Soil Survey Staff 1996). Some relevant characteristics are presented in Table 1.

\subsection{Experimental Design}

The experiment was carried out in 28 containers $(70 \mathrm{~cm}$ long $\times 60 \mathrm{~cm}$ wide $\times$ $40 \mathrm{~cm}$ deep) that were placed outdoors in the experimental farm "La Hampa" (IRNAS-CSIC) in Coria del Río (Southern Spain) (485 $\mathrm{mm}$ mean rainfall, average for 1971-2008; Mean annual daily temperature is around $17^{\circ} \mathrm{C}$, with maximum and minimum temperatures in July of $33.5^{\circ} \mathrm{C}$ and in January of $5.2^{\circ} \mathrm{C}$ ). The containers 
were filled with the upper $20 \mathrm{~cm}$ of the soil $\left(1.32 \mathrm{~g} \mathrm{~cm}^{-3}\right.$ bulk density). Containers were arranged according to a complete randomized block design with seven treatments (four organic, one inorganic and two controls) and four replicates per treatment. The organic treatments were: leonardite (LEO), a low rank coal between peat and sub-bituminous, rich in humic acids from a coal mine (DAYMSA), litter (LIT) collected from a deciduous forest (Castanea sativa Miller.) in the Sierra of Aracena (Huelva, Southern Spain), municipal waste compost (MWC) from a city refuse treatment plant (Villarrasa, Southern Spain), and biosolid compost $(\mathrm{BC})$ constituted from wastewater sludge from a water treatment plant and green waste from parks and gardens (EGMASA, Sevilla, Southern Spain). The inorganic treatment was sugar beet lime (SL), a residual material from the sugar manufacturing process with $70-80 \%$ of $\mathrm{CaCO}_{3}$ (dry basis) (AZUCARERA EBRO, San José de la Rinconada, Southern Spain). Two control treatments without amendments were also established: control with plant (CTRP) and control without plant (CTR). These amendments were chosen because they constitute low-cost, representative materials for land treating extensive areas. The characteristics of the amendments are described in Pérez de Mora et al. (2005). Trace element contents of all amendments were below the limits established by the European Union (CEC 1986) for sewage sludge. The annual loads of trace elements of the products used were also in accordance with the same directive. The amendments were applied on a fresh basis (20-25\% moisture content) and mixed with the topsoil $(10 \mathrm{~cm})$ in the containers. Within the 30 months of the study two doses of each amendment were applied: the first one at the beginning of the experiment $\left(70-75 \mathrm{Mg} \mathrm{dw} \mathrm{ha}^{-1}\right.$ for leonardite and composts and $50-60 \mathrm{Mg}$ $\mathrm{dw} \mathrm{ha}^{-1}$ for sugarbeet lime and litter) and again after 12 months (February 2003) (35.0-37.5 Mg dw ha ${ }^{-1}$ for leonardite and composts and $25-30 \mathrm{Mg} \mathrm{dw} \mathrm{ha}{ }^{-1}$ for sugarbeet lime and litter). The grass Agrostis stolonifera L. was sown (167 $\mathrm{kg} \mathrm{ha}^{-1}$ ) in the containers and grown for 5 months (March-July) for 3 consecutive seasons (2002-2004). A. stolonifera L. was selected because it is known to show metal tolerance. The containers were routinely watered when necessary to maintain plant growth.

\subsection{Soil Sampling and Chemical Analysis}

Soil was sampled on four occasions: $1,6,18$ and 30 months after the beginning of the experiment. In each case, 10 soil cores $(2 \mathrm{~cm}$ diameter, $10 \mathrm{~cm}$ depth) regularly distributed were taken from each container to make a composite sample. Subsamples for chemical analysis were previously air-dried, crushed and sieved ( $2 \mathrm{~mm}$ ). Soil and amendment aliquots for trace element determinations were additionally ground to $60 \mu \mathrm{m}$. Subsamples for microbial biomass and enzymatic activities were sieved $\left(2 \mathrm{~mm}\right.$ ) and stored at $4^{\circ} \mathrm{C}$ until analysis (within two weeks after the sampling). Soil $\mathrm{pH}$ values were measured in a $1: 2.5$ sample: $1 \mathrm{M} \mathrm{KCl}$ extract after shaking for one hour The $0.01 \mathrm{M} \mathrm{CaCl}_{2}$-extractable trace element 
concentrations in soils were determined in 1:10 soil sample $(<2 \mathrm{~mm}): 0.01 \mathrm{M}$ $\mathrm{CaCl}_{2}$ extracts (Ure et al. 1993) via ICP-OES (Inductively coupled plasma-optical emission spectrometry). Total organic carbon (TOC) in soil was analysed by dichromate oxidation and titration with ferrous ammonium sulphate (Walkley and Black 1934).

\subsection{Microbial Biomass and Enzyme Activities}

Microbial biomass carbon (MBC) content was determined by the chloroform fumigation-extraction method modified by Gregorich et al. (1990). The concentration of $\mathrm{C}$ in the extract was measured as described by Jenkinson and Powlson (1976) using dichromate digestion. An extraction efficiency coefficient of 0.38 was used to convert the difference in soluble $\mathrm{C}$ between the fumigated and the unfumigated soil to $\mathrm{MBC}$ (Vance et al. 1987). Dehydrogenase activity (DH) was determined by the method of Trevors (1984), using INT (2 ( $p$-iodophenyl)3-( $p$-nitrophenol) 5-phenyl tetrazolium chloride) as the electron acceptor (García et al. 1993). Arylsulphatase activity (Aryl) was determined as proposed by Tabatabai and Bremmer (1970) after soil incubation with $p$-nitrophenyl sulphate and measurement of $p$-nitrophenol absorbance at $400 \mathrm{~nm}$. $\beta$-glucosidase activity $(\beta$-gluc) was measured as indicated by Tabatabai (1982) after soil incubation with p-nitrophenyl glucoside and measurement of $p$-nitrophenol absorbance at $400 \mathrm{~nm}$. Acid phosphatase activity (Phosph) was measured after soil incubation with p-nitrophenyl phosphate disodium in a $0.5 \mathrm{M}$ maleate buffer $(\mathrm{pH} 6.5)$ and measurement of PNP absorbance at $398 \mathrm{~nm}$ (Nannipieri et al. 1980). Protease activity (Prot) was calculated after incubation of soil with casein and measurement of the absorbance of the extracted tyrosine at $700 \mathrm{~nm}$ (Ladd and Butler 1972).

$\mathrm{DH}$ was expressed in mg INTF $\mathrm{kg}^{-1} \mathrm{dw} \mathrm{h}^{-1}$. Aryl, $\beta$-gluc and Phosph activities were expressed in $\mathrm{mg}$ PNP $\mathrm{kg}^{-1} \mathrm{dw} \mathrm{h} \mathrm{h}^{-1}$. Prot was expressed in mg Tyrosine $\mathrm{kg}^{-1} \mathrm{dw} 2 \mathrm{~h}^{-1}$.

\subsection{Statistical Analysis}

All statistical analyses were carried out with the program SPPS 15.0 for Windows. A normality test was carried out for all variables prior to analysis of the variance. If necessary, non-normal distributed data was transformed accordingly. Differences between treatments within each sampling event for each variable were tested using ANOVA. Post-hoc analysis was performed using Tukey's test for equal variances and Games-Howell's test for unequal variances. To test for time-related differences within the same treatment microbiological data was also analysed by ANOVA for repeated measures using time as factor. Validity of the repeated factor for ANOVA was tested using Mauchly's sphericity test. The Greenhouse-Geisser correction was used for violations of sphericity. Significant differences for all 
variables between the different sampling events within the same treatment were established by Students $t$-test pairwise comparisons using the Bonferroni correction. A $t$-test for unequal variances was computed when these were heterogenous. A correlation matrix between all chemical and biochemical parameters was calculated. The significance level reported $(\alpha=0.01$ and $\alpha=0.05$ ) is based on Pearson's coefficients.

\section{Results and Discussion}

In this study we focused on time-related patterns of various intra-and extracellular enzymatic activities in a soil moderately contaminated with trace elements in which different amendments were applied. Since solubility of As and $\mathrm{Pb}$ was very low, metal-enzyme interactions were only reported for $\mathrm{Cd}, \mathrm{Cu}$ and $\mathrm{Zn}$. Detailed information on biotic and abiotic properties within each sampling can be found elsewhere (Pérez de Mora et al. 2005; Pérez-de-Mora et al. 2006a, b).

Results from microbial biomass $\mathrm{C}(\mathrm{MBC})$ estimations showed various interesting trends. Firstly, the incorporation of amendments into the soil resulted in higher MBC concentrations in all samplings compared to both controls (Fig. la). In the second sampling and subsequently higher microbial biomass yields were recorded in the control with plants than in the control without plants (Fig. 1a). Finally, in most treatments, except LEO and BC, microbial biomass was highest in the second sampling and subsequently decreases (Fig. 1a). The incorporation of amendments and the presence of a rhizosphere in the soil had therefore a stimulatory effect on the soil microbial community. This could be related to the alkalinising effect of the amendments and the incorporation of nutrients and readily degradable organic substrates as suggested by the positive correlations between MBC and soil $\mathrm{pH}$ and nutrient-related properties ( $\mathrm{N}$-Kjeldahl, available-P and water soluble C) (Table 2) (Sakamoto and Oba 1991). The growth of a vegetation cover between the first and second sampling could partly explain why for most treatments $\mathrm{MBC}$ was highest in the second sampling. Plants excrete 10-20\% of their photosynthetates as root exudates, which can be used up by numerous microorganisms as substrates for growth (Salt et al. 1998). In subsequent samplings, however, microbial biomass generally decreased although higher plant yields were achieved (Pérez-de-Mora et al. 2006c). More complex mechanisms may also be involved which may account for this trend such as competition between plants and soil microorganisms for nutrients and/or different degradability of organic matter incorporated with the amendments.

Since microbial biomass is generally higher in soils with higher organic matter content and amendments may also incorporate microorganisms into the soil, it may be useful to normalize shifts in soil microbial biomass $\mathrm{C}$ by using the ratio microbial biomass C/total organic C (MBC/TOC) (Insam and Merschack 1997). A high ratio can be attributed to a highly active microbial population or to easily degradable organic sources, at least for that population (Spargling 1992). Common 

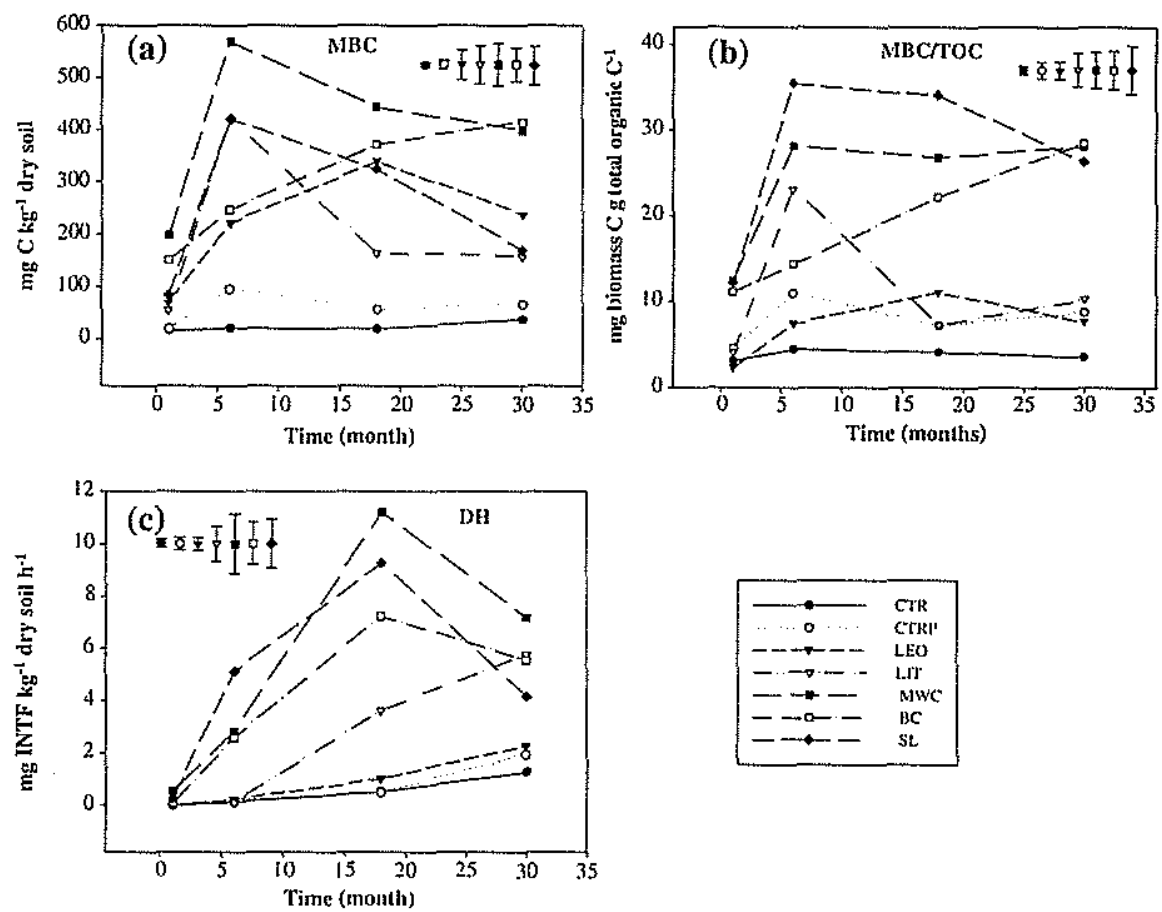

Fig. 1 Temporal dynamics of a microbial biomass $\mathrm{C}, \mathrm{b}$ microbial biomass $\mathrm{C} /$ total organic $\mathrm{C}$ and c dehydrogenase activity. Symbols represent mean values. Error bars represent the maximum standard deviations within one treatment during the whole experiment

values ranged from 10 to $40 \mathrm{mg} \mathrm{MBC} \mathrm{g}^{-1} \mathrm{TOC}$ (Gigliotti and Farini 2002). The ratio showed a very similar pattern for all treatments to that of MBC (Fig. 1b). In the case of the compost and sugarbeet lime amended soils the ratio was significantly higher in all samplings compared to both controls. Nonetheless, in soils amended with litter and leonardite differences with the controls were not significant. On occasions similar values were observed in the control with plant and the amended soils. These results suggest that microorganisms may be incorporated with the amendments (hence higher $\mathrm{MBC}$ yields), but also that litter and leonardite are not as good as composts or lime to stimulate microbial growth in degraded soils. The fact that plant litter needs first to be cut down into smaller fractions for more effective microbial attack and the recalcitrant nature of organic $\mathrm{C}$ from the leonardite may explain these results.

Enzymatic patterns were enzyme-and treatment-dependent showing the extreme complexity of ecological reactions occurring in the soil. Dehydrogenase activity has been used to assess heavy metal toxicity in soils (Rossel et al. 1997) and microbial activity in semiarid Mediterranean areas (García et al. 1997). During the experiment higher $\mathrm{DH}$ was recorded in all treated soils compared to controls, except LEO (Fig. 1c). This enzyme was positively correlated with MBC, but there 
Table 2 Correlation coefficients between chemical and biochemical properties

\begin{tabular}{lccccccc}
\hline & MBC/TOC & MBC & DH & Aryl & $\beta-$ gluc & Phosph & Prot \\
\hline pH & $0.565^{\mathrm{a}}$ & $0.450^{\mathrm{a}}$ & $0.616^{\mathrm{a}}$ & $0.379^{\mathrm{a}}$ & -0.007 & $-0.322^{\mathrm{a}}$ & $0.318^{\mathrm{a}}$ \\
Sol-Cd & $-0.415^{\mathrm{a}}$ & $-0.411^{\mathrm{a}}$ & $-0.561^{\mathrm{a}}$ & $-0.343^{\mathrm{a}}$ & -0.159 & -0.023 & $-0.482^{\mathrm{a}}$ \\
So-Cu & $-0.368^{\mathrm{a}}$ & $-0.428^{\mathrm{a}}$ & $-0.403^{\mathrm{a}}$ & $-0.254^{\mathrm{a}}$ & $-0.308^{\mathrm{a}}$ & $-0.213^{\mathrm{b}}$ & $-0.449^{\mathrm{a}}$ \\
Sol-Zn & $-0.502^{\mathrm{a}}$ & $-0.471^{\mathrm{a}}$ & $-0.616^{\mathrm{a}}$ & $-0.360^{\mathrm{a}}$ & $-0.246^{\mathrm{a}}$ & -0.080 & $-0.530^{\mathrm{a}}$ \\
TOC & $-0.221^{\mathrm{b}}$ & $-0.202^{\mathrm{b}}$ & $-0.223^{\mathrm{b}}$ & -0.117 & -0.105 & 0.034 & -0.011 \\
N-Kjeld & $0.312^{\mathrm{a}}$ & $0.574^{\mathrm{a}}$ & $0.465^{\mathrm{a}}$ & $0.632^{\mathrm{a}}$ & $0.384^{\mathrm{a}}$ & $0.208^{\mathrm{b}}$ & $0.266^{\mathrm{a}}$ \\
Avail-P & $0.304^{\mathrm{a}}$ & $0.250^{\mathrm{a}}$ & $0.223^{\mathrm{b}}$ & 0.059 & -0.181 & $-0.287^{\mathrm{a}}$ & -0.054 \\
WC & $0.527^{\mathrm{a}}$ & $0.665^{\mathrm{a}}$ & $0.356^{\mathrm{a}}$ & $0.687^{\mathrm{a}}$ & $0.544^{\mathrm{a}}$ & $0.388^{\mathrm{a}}$ & $0.330^{\mathrm{a}}$ \\
MBC/TOC & 1 & $0.852^{\mathrm{a}}$ & $0.598^{\mathrm{a}}$ & $0.510^{\mathrm{a}}$ & $0.192^{\mathrm{b}}$ & -0.088 & $0.266^{\mathrm{a}}$ \\
MBC & & 1 & $0.498^{\mathrm{a}}$ & $0.568^{\mathrm{a}}$ & $0.384^{\mathrm{a}}$ & 0.156 & $0.310^{\mathrm{a}}$ \\
DH & & 1 & $0.585^{\mathrm{a}}$ & $0.227^{\mathrm{b}}$ & -0.093 & $0.485^{\mathrm{a}}$ \\
Aryl & & & 1 & $0.383^{\mathrm{a}}$ & 0.143 & $0.224^{\mathrm{b}}$ \\
$\beta$-glu & & & & 1 & 1 & $0.724^{\mathrm{a}}$ & $0.393^{\mathrm{a}}$ \\
Phosph & & & & & & 1 & $0.331^{\mathrm{a}}$ \\
Prot & & & & & & & 1 \\
\hline
\end{tabular}

"Correlation is significant at the 0.01 level

${ }^{b}$ Correlation is significant at the 0.05 level

seemed to be a delay in $\mathrm{DH}$ response to remediation practices compared to $\mathrm{MBC}$; in most cases DH values were highest in the third sampling (Fig. 1c). Due to its intracellular nature $\mathrm{DH}$ is usually better correlated to microbial biomass dynamics than extracellular enzymes (Pérez-de-Mora et al. 2008). Values of DH were significantly higher in the third and fourth samplings for most of the treatments except for CRT. These results may be therefore influenced by the higher sensitivity of DH to soil acidity compared to extracellular enzymes as the positive correlation between this activity and soil $\mathrm{pH}$ suggests (Table 2). In fact, soil $\mathrm{pH}$ in all treatments increased as time progressed including control soils (Pérez-de-Mora et al. 2006d).

Temporal dynamics of extracellular activities were very variable. Similarities with the activity patterns of other biochemical parameters estimated such as $\mathrm{MBC}$ and DH were only found for Aryl (Fig. 2). Here soils amended with composts and SL showed the largest activity (Fig. 2a). As observed for DH, the highest activity values were recorded in the third sampling. In the other treatments (LIT, LEO, CTR, CTRP) little variation was found during the experiment (Fig. 2a). Temporal and treatment induced differences for Aryl may be related to changes in soil pH and trace element availability as the correlations between these parameters indicate (Table 2). In fact, this activity has been outlined as a very sensitive enzyme in tracing heavy metal effects (Hinojosa et al. 2008). Given that $\mathrm{SO}_{4}{ }^{-2}$ availability is enhanced as soil $\mathrm{pH}$ increases and sulphides from the spill should act as the main source of $\mathrm{SO}_{4}^{-2}$ anions in all treatments, data suggests that Aryl was less affected by sulphate concentrations in soil than by the $\mathrm{pH}$ or metal concentrations.

Results from $\beta$-gluc, Phosph and Prot differed from the rest of biological parameters studied (Fig. 2b-d). This may be explained by the fact that 

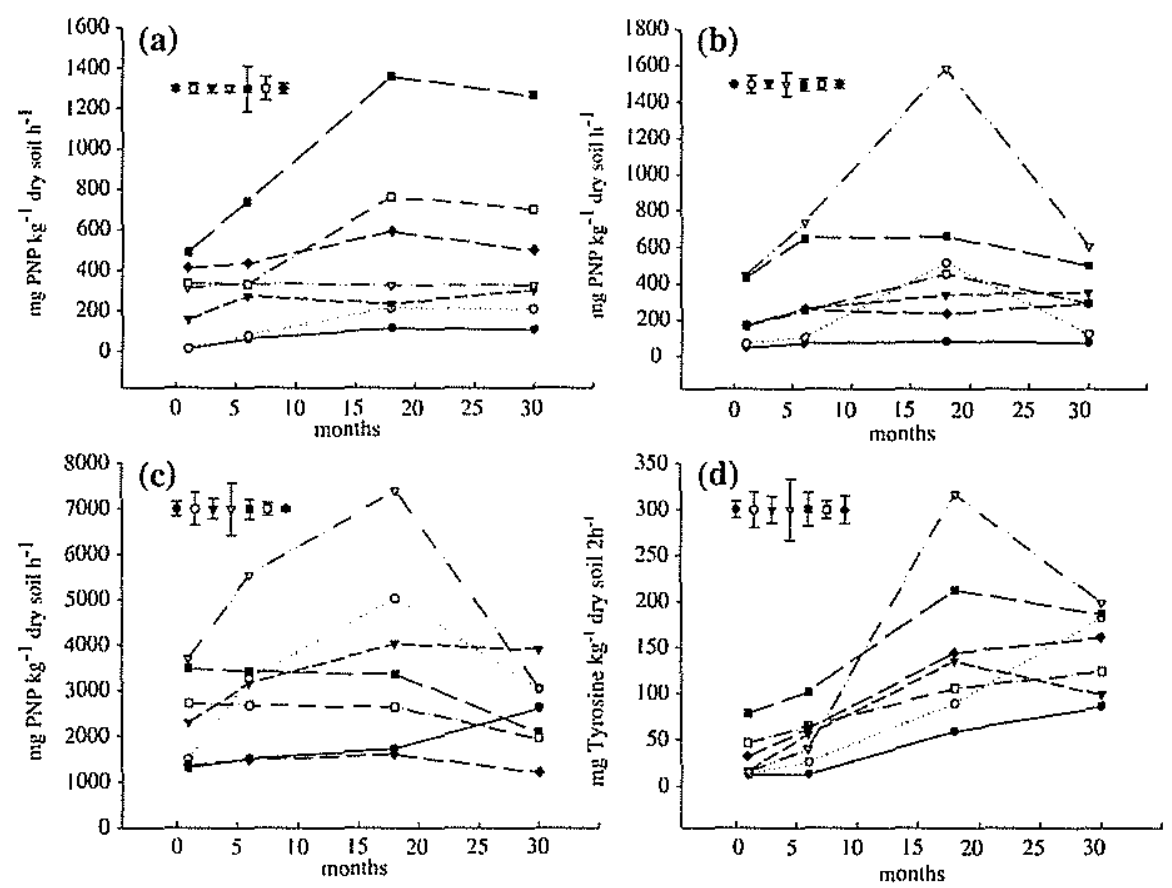

$$
\begin{aligned}
& \longrightarrow \text { CTR } \rightarrow \rightarrow-\infty \text { LEO } \longrightarrow-\text { MWC } \rightarrow-\text { SL. } \\
& \text { CTRP }-\rightarrow \cdots \text { LIT } \quad-\cdots-D C
\end{aligned}
$$

Fig. 2 Temporal dynamics of a aryl-sulphatase $C, \mathbf{b} \beta$-glucosidase $\mathbf{c}$ acid-phosphatase and d protease. Symbols represent mean values. Error bars represent the maximum standard deviations within one treatment during the whole experiment

concentrations of the substrates and the final products resulting from these activities could be highly influenced by the incorporation of amendments and the development of a plant cover. In the first case, enzymatic activity would be promoted as more substrate is present. On the other hand, if the final products of enzymatic reactions accumulate and are readily available, enzymatic release and hence potential activity might decrease (feedback inhibition). In the case of $\beta$-gluc little temporal variations were recorded during the experiment, except in the LIT and CTRP treatments in which mean values for the third sampling event were significantly higher than those found in the other treatments (Fig. 2b). Both LIT and CTRP showed a significant increase in $\beta$-gluc between the second and the third samplings followed by a sharp decrease in activity towards the end of the experiment (Fig. 2b). This trend could be related to a significant improvement in vegetation cover in these two treatments between the second and the third sampling (Pérez-de-Mora et al. 2006c). In the other amended soils incorporation of C substrates through the addition of amendments and the presence of a healthy plant 
cover from the beginning of the experiment could account for a more homogeneous $\mathrm{C}$ pool in the soil and thus a more constant pattern of $\beta$-gluc over time.

Acid-phosphatase showed a similar trend as $\beta$-gluc in the LIT and CTRP treatments (Fig. 2c). For the other soils different results were observed: in the case of LEO, Phosph increased as time progressed, whereas in CTR potential activity remained low until the third sampling and it increased sharply towards the end of the experiment. It is possible that improved soil conditions in these treatments at the end of the experiment (f.ex. less acid pH in CTR) could account for higher potential activity values (Fig. 2c). In contrast, soils amended with composts and SL showed a decrease in Phosph at the end of the experiment (Fig. 2c). This might be due to feedback inhibition of the enzyme by inorganic phosphate as suggested by the negative correlation between acid-phosphatase and available-P (Table 2). These results are also in agreement with data reported by other authors for other soils into which amendments with a high $\mathrm{P}$ content were incorporated (Madejón et al. 2003, Plaza et al. 2004).

Protease activity generally increased in all treatments as time progressed, except in LIT, where a similar pattern as for $\beta$-gluc and Phosph was observed (Fig. 2d). Prot was negatively correlated with soluble heavy metal concentrations and positively correlated with soil $\mathrm{pH}$ (Table 2). Therefore amelioration of soil properties and metal availability could partly account for this general trend. In addition, temporal variations in $\mathrm{N}$ availability related to amendment incorporation, plant maturity and mineralization processes could also influence Prot in the soil as the positive correlation between protease and $\mathrm{N}$-Kjeldahl indicates (Table 2). Other authors have also reported positive but rather weak correlations between these two variables arguing that the complex nature of organic $N$ (Schulten and Schnitzer 1998, Wick et al. 2002) and the substrate specificity of the various extracellular proteases (Kalisz 1988) may account for this observation.

\section{Conclusions}

- The incorporation of amendments and/or development of a plant cover show great potential for stabilizing trace elements in soil in the mid-term, enhancing nutrient cycling and microbial activity at the same time.

- Due to their alkaline nature, composts and sugarbeet lime performed better than other amendments and thus have more potential for field application. However, once a vegetation cover has established, amendment additions may be unnecessary or kept at a minimum.

- Remediation practices showed a positive effect on soil functionality which is enzyme and treatment dependent. Enzymatic activities such as dehydrogenase, aryl-suplhatase and protease seem to be more sensitive to changes in soil $\mathrm{pH}$ and trace element availability than $\beta$-glucosidase and acid-phosphatase, which seem to be more strongly influenced by substrate or enzymatic product availability. 
- The utilization of microbial enzymatic assays for assessing soil remediation practices can be very helpful, but various activities are required for diagnostic monitoring of soil restoration.

\section{References}

Bolan NS, Duraisamy VP (2003) Role of inorganic and organic soil amendments on immobilisation and phytoavailability of heavy metals: a review involving specific case studies. Aust J Soil Res 41:533-555

CEC (Commission of the European Communities), 1986. Council Directive 86/278/EEC of 12 June 1986 on the protection of the environment, and in particular of the soil, when sewage sludge is used in agriculture. Official J L181, 04/07/1986, pp. 6-12

Ellis RJ, Morgan P, Weightman AJ, Fry JC (2003) Cultivation-dependant and-independant approaches for determining bacterial diversity in heavy-metal contaminated soil. Appl Environ Microbiol 69:3223-3230

García C, Hernández T, Costa F (1997) Potential use of dehydrogenase as an index of microbjal activity in degraded soils. Cornmun Soil Sci Plan 28:123-134

Gigliotti C, Farini F (2002) Microbial biomass response to heavy metals in the field. In: Violante A, Huang PM, Bollag JM, Gianfreda L (eds) Soil mineral-organic matter-microorganisms interactions and ecosystem health. Developments in soil science, vol 28B. Elsevier Science B.V, Amsterdam/New York, pp 195-204

Giller KE, Witter E, McGrath SP (1998) Toxicity of heavy metals to microorganisms and microbial processes in agricultural soils: a review. Soil Biol Biochem 30:1389-1414

Gregorich EG, Wen G, Voroney RP, Kachanoski RG (1990) Calibration of rapid direct chloroform extraction method for measuring soil microbial biomass C. Soil Biol Biochem 22:1009-101 I

Hinojosa MB, Rodríguez-Maroto JM, García-Ruíz R, Carreira JA (2008) Effects of pyrite sludge pollution on soil enzyme activities: Ecological dose-response model. Sci Total Environ 396:89-99

Insam H, Merschack P (1997) Nitrogen leaching from forest soil cores after amending organic recycling products and fertilizers. Waste Manage Res 15:277-292

Iskandar IK, Adriano DC (1997) Remediation of soil contaminated with metals. Science Reviews, Aberystswyth, UK

Jenkinson DS, Powlson DS (1976) The effect of biocidal treatment in metabolism of soil: A method for measuring microbial biomass. Soil Biol Biochem 8:209-213

Kalisz HM (1988) Microbial proteinases. Adv Biochem Eng Biotechnol 36:3-65

Kandeler E, Tscherko D, Bruce KD, Stemmer M, Hobbs PJ, Bardgett RD, Amelung W (2000) Structure and function of the soil microbial community in microhabitats of a heavy metal polluted soil. Biol Fertil Soils 30:390-400

Ladd JN, Butler JHA (1972) Short-term assays of soil proteolytic enzyme activities using proteins and dipeptide derivatives as substrates. Soil Biol Biochem 4:19-30

Madejón E, Burgos P, López R, Cabrera F (2003) Agricultural use of three organic residues: Effect on orange production and on properties of a soil of the "Comarca Costa de Huelva" (SW Spain). Nutr Cycl Agroecosyst 65:281-288

Madejón E, Pérez-de-Mora A, Felipe E, Burgos P, Cabrera F (2006) Soil amendments reduce trace element solubility in a contaminated soil and allow regrowth of natural vegetation. Environ Pollut 139:40-52

Nannipieri P, Ceccanti B, Cervelli S, Matarese E (1980) Extraction of phosphatase, urease, protease, organic carbon and nitrogen from soil. Soil Sci Soc Am J 44:1011-1016 
Nannipieri P, Kandeler E, Ruggiero P (2002) Enzyme activities and microbiological and biochemical processes in soil. In: Burns RG, Dick RP (eds) Enzymes in the environment, activity, ecology and applications. Marcel Dekker, New York, pp 1-33

Pérez de Mora A, Ortega-Calvo JJ, Cabrera F, Madejón E (2005) Changes in enzyme activities and microbial biomass after "in situ" remediation of a heavy metal-contaminated soil. Appl Soil Ecol 28:125-137

Pérez-de-Mora A, Burgos P, Madejón E, Cabrera F, Jaeckel P, Schloter M (2006a) Mícrobial community structure and function in a soil contaminated by heavy metals: effect of plant growth and different amendments. Soil Biol Biochem 38:327-341

Pérez-de-Mora A, Burgos P, Ortega-Calvo JJ, Cabrera F, Madejón E (2006b) Microbial function after assisted natural remediation of a trace element polluted soil. In: A. Méndez-Vilas (Ed) Modern Multidisciplinary Applied Microbiology. Understanding and Exploiting Microbes and Their Interactions. Biological, Physical, Chemical and Engineering Aspects. Wiley-VCH, pp 536-540

Pérez-de-Mora A, Burgos P, Cabrera F, Madejón E (2006c) Trace elements availability and plant growth in a mine-spill-contaminated soil under assisted natural remediation. Part I. Soils. Sci Total Environ 363:28-37

Pérez-de-Mora A, Burgos P, Cabrera F, Madejón E (2006d) Trace elements availability and plant growth in a mine-spill-contaminated soil under assisted natural remediation. Part II. Plants. Sci Total Environ 363:38-45

Pérez-de-Mora A, Madejón E, Cabrera F, Buegger F, Fuß R, Pritsch K, Schloter M (2008) Longterm impact of acid resin waste deposits on soil quality of forest areas II. Biological indicators. Sci Total Environ 406:99-107

Plaza C, Hernández D, García-Gil JC, Polo A (2004) Microbial activity in pig slurry-amended soils under semiarid conditions. Soil Biol Biochem 36:1577-1585

Rossel D, Tarradellas J, Bittom G, Morel JL (1997) Use of enzymes in soil ecotoxicology: a case for dehydrogenase and hydrolitic enzymes. In: Tarradellas J, Bitton G, Rossel D (eds) Soil ecotoxicology. Lewis Publishers, CRC Press, Boca Ratón, Florida, pp 179-206

Sakamoto K, Oba Y (1991) Relationship between the amount of organic material applied and soil biomass content. Soil Sci Plant Nutr 37:387-397

Salt DE, Smith RD, Raskin I (1998) Phytoremediation. Annu Rev Plant Physiol Plant Mol Biol 49:643-668

Schulten HR, Schnitzer M (1998) The chemistry of soil organic nitrogen: a review. Biol Fertil Soils $26: 1-15$

Soil Survey Staff (1996) Keys to soil taxonomy. US department of agriculture, soil conservation service, Washington DC

Spargling GP (1992) Ratio of microbial biomass carbon to soil organic carbon as sensitive indicator of changes in soil organic matter. Aust J Soil Res 39:195-207

Tabatabai MA (1982) Soil enzymes. In: Page AL, Miller EM, Keeney DR (eds) Methods of Soil Analyses, Part 2, Chemical and Microbiological Properties. American Society of Agronomy, Madison, WI, pp 903-947

Tabatabai MA, Bremmer JM (1970) Arylsulphatase activity of soils. Soil Sci Soc Am Proc 34:225-229

Tordoff GM, Baker AJM, Willis AJ (2000) Current approaches to the revegetation and reclamation of metalliferous wastes. Chemosphere 41:219-228

Trevors JT (1984) Dehydrogenase activity in soil: a comparison between the INT and the TTC assay. Soil Biol Biochem 16:673-674

Vance ED, Brookes PC, Jenkinson DS (1987) Microbial biomass measurements in forests soils: determination of $\mathrm{K}_{\mathrm{c}}$ values and test of hypothesis to explain the failure of the chloroform fumigation-incubation method in acid soils. Soil Biol Biochem 19:381-387

Walkley A, Black IA (1934) An examination of the Degtjareff method for determining soil organic matter and a proposed determination of the chromic acid tritation method. Soil Sci $37: 29-38$ 
Wick B, Kühne RF, Vielhauer K, Vleck PLG (2002) Temporal variability of selected soil microbiological and biochemical indicators under different soil quality conditions in southwestern Nigeria. Biol Fertil Soils 35:155-167

Ure AM, Quevauviller PH, Muntau H, Griepink B (1993) Speciation of heavy metals in soils and sediments. An account of the improvement and harmonisation of extraction techniques undertaken under the auspices of the BCR of the Comission of the European Communities. Int J Environ Anal Chem 51:135-151 